\title{
INFLUENCE OF URBANIZATION ON LAND SURFACE TEMPERATURE IN RECIFE CITY
}

\section{TACIANA O. DOS SANTOS ${ }^{1}$, GEBER B. DE A. MOURA ${ }^{2}$, BERNARDO B. DA SILVA ${ }^{3}$, LEIDJANE M. M. DE OLIVEIRA ${ }^{4}$, CELIA C. C. MACHADO ${ }^{5}$}

\begin{abstract}
Urbanization has caused significant environmental impacts, replacing natural surfaces by buildings, decreasing green vegetated areas, soil sealing and atmospheric pollution which contribute to increase the land surface temperature in such areas. Thus, this study aimed to analyze the influence of urbanization on land surface temperature (Ts) in Recife city - Pernambuco (PE), in Brazil, using the Thematic Mapper (TM) sensor images from Landsat 5 satellite. To perform the study, images of August 4, 1998 and September 6, 2010 were obtained and processed to generate Ts thematic maps of Recife-PE and of two districts of this city (Curado and Casa Amarela), in order to analyze the transformation dynamics that has occurred in the area. Through the profile produced for the study area, a spatial and temporal increase of the Ts surface was noticeable in the suburb-downtown direction: $6^{\circ} \mathrm{C}$ of difference between these areas. The Casa Amarela district, with high urban concentration, presented the highest Ts values observed $\left(>27^{\circ} \mathrm{C}\right)$.
\end{abstract}

KEYWORDS: urban climate, Landsat, ambient comfort, thermal infrared.

\section{INFLUÊNCIA DA URBANIZAÇÃO SOBRE A TEMPERATURA DA SUPERFÍCIE NA CIDADE DE RECIFE-PE}

RESUMO: A urbanização vem causando consideráveis impactos ambientais, em consequência da substituição das superfícies naturais por edificações, redução de áreas verdes, impermeabilização do solo e da poluição atmosférica, contribuindo, desta forma, param a elevação da temperatura nesses locais. Assim, este trabalho objetivou analisar a influência da urbanização sobre a temperatura da superfície (Ts) na cidade de Recife-PE, a partir de imagens do sensor Thematic Mapper (TM) do satélite Landsat 5. Para a realização do estudo, foram obtidas imagens de 4 de agosto de 1998 e de 6 de setembro de 2010, que foram empregadas na geração de mapas temáticos de Ts da cidade do Recife e mais detalhadamente em dois bairros da cidade (Casa Amarela e Curado), a fim de analisar a dinâmica da transformação ocorrida nessas áreas. Por meio do perfil desenvolvido para área de estudo, foi perceptível o aumento espacial e temporal da Ts no sentido subúrbio-centro, resultando em uma diferença de $6^{\circ} \mathrm{C}$ entre essas áreas. O bairro de Casa Amarela, por possuir maior adensamento urbano, apresentou temperaturas mais elevadas $\left(>27^{\circ} \mathrm{C}\right)$.

PALAVRAS-CHAVE: clima urbano, Landsat, conforto ambiental, infravermelho termal.

\footnotetext{
${ }^{1}$ Engenheira Agrônoma, Mestre em Engenharia Agrícola, Depto. de Tecnologia Rural, Universidade Federal Rural de Pernambuco (UFRPE), Recife-PE, taciolisantos@yahoo.com.br.

${ }^{2}$ Meteorologista, Prof. Doutor, Depto. de Agronomia, Universidade Federal Rural de PernambucoUFRPE), Recife-PE, geber@depa.ufrpe.br.

${ }^{3}$ Meteorologista, Prof. Doutor, Depto. de Engenharia Civil, Universidade Federal de Pernambuco (UFPE), Recife-PE, bbdasilva.ufpe@gmail.com.

${ }^{4}$ Engenheira Civil, Doutora, Bolsista Pós-Doutorado CAPES/FACEPE/APAC, Depto. de Engenharia Civil, Universidade Federal de Pernambuco (UFPE), Recife-PE, leidjaneoliveira@ hotmail.com.

${ }^{5}$ Bióloga, Doutoranda, Depto. de Ciências Geográficas, Universidade Federal de Pernambuco (UFPE), Recife-PE, celiamachado.machado@gmail.com.

Recebido pelo Conselho Editorial em: 1-11-2012

Aprovado pelo Conselho Editorial em: 4-3-2013
} 


\section{INTRODUCTION}

The changes resulting from anthropic activities through urban growth have generated impacts on climate, which are intensified by constant changes of the space, causing imbalance in the interactions between surface and atmosphere. In this space built and constantly modified by various forms of land use, there are often some changes in meteorological elements such as temperature and air humidity, resulting in different microclimates and the formation of heat islands (FEITOSA et al., 2011.)

The urban climate has been intensively investigated in cities located in the middle and high latitudes in countries of North America and Europe. Scientific knowledge accumulated in these studies has supported government actions of planning and management to ensure standards of quality of life of urban populations in these regions. On the other hand, the systematic worsening of environmental problems in cities located in regions of tropical and subtropical climates has revealed the immense existing liability in scientific knowledge relating to changes induced by urbanization in the climate of these regions (ROTH, 2007).

The replacement of the natural landscape by buildings and paved surfaces alters the aerodynamic properties (aerodynamic roughness) and radiative surface (albedo and effective emissivity), thermal properties of the substrate (capacity, conductivity and thermal admittance), and the hydraulic properties of the soil surface (surface permeability, hydraulic capacity and hydraulic conductivity) (FERREIRA et al., 2012).

In large urban centers, the reduction of green areas and modifications occurred on the soil surface causes an increase of the surface and air temperature in contact with that surface. According to SILVA et al. (2011) although there is a reduction in radiative balance, since these changes in land occupation increases albedo and Ts, a large amount of radiation that was used in the evaporation of water from soil and vegetation, is now employed in the heating of soil and air. This effect is most evident in water mirrors, which have low albedo and although they have high radiative balance, the greater number is applied to the evaporation of water, resulting in very low Ts. The role of the replacement of vegetation cover resulting from the urbanization process has been well documented in other studies (OKE \& MAXWELL, 1975; CHISTEN \& VOLGT, 2004; KATO \& YAMAGUICHI, 2005). The countryside or the suburbs of the metropolis, according to those same researchers, have greater radiative balance, but portion of it is used in the evaporation of water retained in the soil and vegetation. As a result, is evidenced in anthropic urban areas a substantial increase in surface and air temperatures (SILVA et al., 2011; RITTER, 2011).

The surface temperature (Ts) has significant scientific importance in climatology and urbanization, as in the modeling of the energy balance (HONORATO \& ANDRADE, 2012) and biophysical and bioclimatic parameters of the surface. Thus, its estimation is of great utility in monitoring study of urban climate, and may contribute to the identification of changes in climatic elements in the urban environment (CODATO et al., 2008).

Through thermal images obtained through remote sensing is possible to detect thermal characteristics of urban surface (CHANDER et al., 2009). One of the main applications of remote sensing in the study of urban climates is to analyze the relation between the spatial structure of the urban thermal patterns and urban surface characteristics, which can assist the planning of the use and occupation of land (CHEN et al., 2006).

In recent decades, Recife city - Pernambuco (PE), in Brazil, was submitted to an intense process of densification of buildings, which has caused significant environmental impacts (GALVÍNCIO \& MOREIRA, 2007). One of the consequences of the uncontrolled urbanization process is the change in the urban climate, with increased thermal discomfort of inhabitants (MOREIRA et al., 2011). Accordingly, the present study aimed to analyze the influence of urbanization on surface temperature in the city of Recife-PE, from TM images of Landsat 5. 


\section{MATERIAL AND METHODS}

The study area is the city of Recife, located in the eastern portion of the Northeast, in the South Atlantic coast of Pernambuco state. According to IBGE (2012), the city has a population of $1,537,704$ inhabitants spread over an area of $217.5 \mathrm{~km}^{2}$ which results in a density of 7180.23 inhabitants per $\mathrm{km}^{2}$. This city lies between latitudes $7^{\circ} 55^{\prime} 00^{\prime \prime}$ and $8^{\circ} 10^{\prime} 00^{\prime \prime} \mathrm{S}$ and longitude $34^{\circ} 51^{\prime} 00^{\prime \prime}$ and $35^{\circ} 01^{\prime} 00^{\prime \prime} \mathrm{W}$, with an average altitude of $4 \mathrm{~m}$, which also has an extensive river system inserted in its urban sprawl.

The city climate is characterized by being hot and humid (AS') with rains from autumn to winter. The region, being located in an area of low latitude, presents monthly average temperatures around $25^{\circ} \mathrm{C}$, with the months of January and February being the hottest, with temperatures exceeding $26^{\circ} \mathrm{C}$. The months of July and August have temperatures at or below $24^{\circ} \mathrm{C}$. The relative air humidity presents annual average of $84 \%$ (MOREIRA et al., 2011).

We used two TM images from the Landsat 5 satellite, obtained from the National Institute for Space Research (INPE - Instituto Nacional de Pesquisas Espaciais) corresponding to the passage of the satellite over the city of Recife in the days of August 4, 1998 and September 6, 2010, at 09:07 and 09:19 local time, respectively, in 214 orbit and 66 and 65 points.

Before starting the process of digital images treatment, we performed a pre-processing that consists in band to band stacking. Then the images were mosaicked and resampled to UTM projection with pixel size of $30 \mathrm{~m} \times 30 \mathrm{~m}$, after being registered by the first order polynomial geometric correction. Subsequently, the images were cropped according to the limit of the city of Recife and then processed, providing the generation of thematic maps of Ts.

To obtain the Ts (K) we used the inverted Planck equation (DI PACE et al., 2008; COSTA et al., 2010):

$$
\mathrm{Ts}=\frac{\mathrm{K}_{2}}{\ln \left(\frac{\varepsilon_{\mathrm{NB}} \mathrm{K}_{1}}{\mathrm{~L}_{6}}+1\right)}
$$

in which: $\mathrm{K}_{1}=607.76 \mathrm{Wm}^{-2} \mathrm{sr}^{-1} \mu \mathrm{m}^{-1}$ and $\mathrm{K}_{2}=1260.56 \mathrm{~K}$ are specific radiation constants of $\mathrm{TM}, \varepsilon_{\mathrm{NB}}$ is the emissivity of each image pixel in the thermal band domain (dimensionless) and $\mathrm{L}_{6}\left(\mathrm{Wm}^{-2} \mathrm{sr}^{-}\right.$ $\left.{ }^{1} \mu \mathrm{m}^{-1}\right)$ is the monochromatic radiance of the band 6 of TM.

The spectral radiance of band 6 , as well as bands 3 and 4 used in the computation of reflectance used in $\varepsilon_{\mathrm{NB}}$ computation were obtained by radiometric calibration, i.e. by the transformation of the gray level of each pixel in spectral radiance L $_{\lambda \mathrm{i}}$ (ALLEN et al., 2007; SILVA et al., 2008; OLIVEIRA et al., 2012):

$$
\mathrm{L}_{\mathrm{\lambda}_{\mathrm{i}}}=a_{i}+\left(\frac{b_{i}-a_{i}}{255}\right) \mathrm{ND}
$$

in which: $a$ and $b$ are the minimum and maximum spectral radiances $\left(\mathrm{Wm}^{-2} \mathrm{sr}^{-1} \mu \mathrm{m}^{-1}\right)$ and ND is the pixel intensity (whole number between 0 and 255). Its calibration coefficients and spectral irradiance in atmosphere top are shown in Table 1.

TABLE 1. Description of bands 3, 4 and 6 of the TM - Landsat 5 corresponding to the minimum (a) and maximum (b) calibration coefficients and the spectral irradiance in the top of

\begin{tabular}{|c|c|c|c|c|c|c|}
\hline \multirow{3}{*}{ Bands } & \multirow{3}{*}{$\begin{array}{c}\text { Spectral } \\
\text { Range }(\mu \mathrm{m})\end{array}$} & \multicolumn{4}{|c|}{ Coefficient of Calibration $\left(\mathrm{Wm}^{-2} \mathrm{sr}^{-1} \mu \mathrm{m}^{-1}\right)$} & \multirow{3}{*}{$\begin{array}{c}\text { TOA } \\
\left(\mathrm{Wm}^{-2} \mu \mathrm{m}^{-1}\right)\end{array}$} \\
\hline & & \multicolumn{2}{|c|}{$03 / 01 / 1984$ to $05 / 04 / 2003$} & \multicolumn{2}{|c|}{ After 04/02/2007 } & \\
\hline & & $\mathrm{a}$ & $\mathrm{b}$ & $\mathrm{a}$ & $\mathrm{b}$ & \\
\hline 3 - red & $0.63-0.69$ & -1.17 & 204.30 & -1.17 & 264.00 & 1554.0 \\
\hline 4 - near & $0.76-0.90$ & -1.51 & 206.20 & -1.51 & 221.00 & 1036.0 \\
\hline 6 - thermal & $10.4-12.5$ & 1.2378 & 15.303 & 1.2378 & 15.303 & - \\
\hline
\end{tabular}
atmosphere (TOA). 
The $\varepsilon_{\mathrm{NB}}$ emissivity was obtained by parameterized equation in function of the Leaf Area Index LAI $\left(\mathrm{m}^{2} \mathrm{~m}^{-2}\right)$ (ALLEN et al., 2007; BEZERRA et al., 2008):

$$
\varepsilon_{\mathrm{NB}}=0.97+0.0033 \mathrm{LAI}
$$

valid for $0<\mathrm{LAI}<3$. In cases in which $\mathrm{LAI}<3$, we adopted for $\varepsilon_{\mathrm{NB}}$ a value constant and equal to 0.985 (ALLEN et al., 2007; SILVA et al., 2011; RODRIGUES et al., 2009). The LAI was determined in function of SAVI - Soil-Adjustment Vegetation Index, following the parameterization proposed by TASUMI et al. (2008):

$$
\mathrm{IAF}=-\frac{\ln \left(\frac{0,69-\text { SAVI }}{0,59}\right)}{0,91}
$$

in which the SAVI was obtained by the following equation (HUETE, 1988):

$$
S A V I=\frac{(1+L)\left(\rho_{V V}-\rho_{V}\right)}{\left(L+\rho_{I V}+\rho_{V}\right)}
$$

in which: $\rho_{V V}$ is the reflectance of the near-infrared (band 4), $\rho_{V}$ is the reflectance of the red (band 3 ) and L is constant, with value equal to 0.5. The Normalized Difference Vegetation Index (NDVI) was obtained by the reason between the reflectivity of the near-infrared $\left(\rho_{i v}\right)$ and the red $\left(\rho_{v}\right)$, by the sum of them (RODRIGUES et al., 2009):

$$
N D V I=\frac{\rho_{I V}-\rho_{V}}{\rho_{I V}+\rho_{V}}
$$

The NDVI serves as a sensitive indicator of the quantity and condition of vegetation. Their values range from -1 to +1 , with positive values corresponding to areas with some type of vegetation, while negative values represent surfaces with water. This index is widely used in mapping areas, the detection of changes in land use and land occupation. For this reason it was used in the preparation of the Ts profile of Recife-PE.

The reflectance of bands 3 and 4 employed in NDVI and SAVI calculation correspond to the ratio between the radiation reflected by each band flow and the incident solar radiation flow (OLIVEIRA et al., 2012; BEZERRA et al., 2008):

$$
\rho_{\lambda i}=\frac{\pi L_{\lambda i}}{\left(k_{\lambda i} \cdot \cos Z \cdot d r\right)}
$$

in which: $\mathrm{k}_{\lambda_{\mathrm{i}}}$ is the solar irradiance of each band (3 and 4) in the atmosphere top, $\mathrm{Z}$ is the solar zenithal angle, and $\mathrm{dr}$ is the inverse square of the relative distance Earth-Sun, in a given day of the year (Table 1).

\section{RESULTS AND DISCUSSION}

Figures 1A and 1B depict the thematic maps of Ts, concerning the days selected for the study. The lowest values are represented by the areas of blue tones, areas with greater presence of vegetation and water features, recording values lower than $23^{\circ} \mathrm{C}$. Similar estimates were found by COSTA et al. (2010) in a study of the urban sprawl of Ilha Solteira city - São Paulo (SP), in Brazil, with TM images - Landsat 5, in vegetated areas, with values between $20-23^{\circ} \mathrm{C}$. FEITOSA et al. (2011) also obtained values of Ts between $22-25^{\circ} \mathrm{C}$ in green spaces, through analysis of the removal of vegetation due to urban expansion in 20 years and the formation of the thermal field to estimate the Ts of the urbanized area of Teresina city - Piauí (PI) state, in Brazil, also using TM images Landsat 5. In the same range of blue tones are embedded areas with water features, presenting Ts similar to those recorded in vegetation areas. 


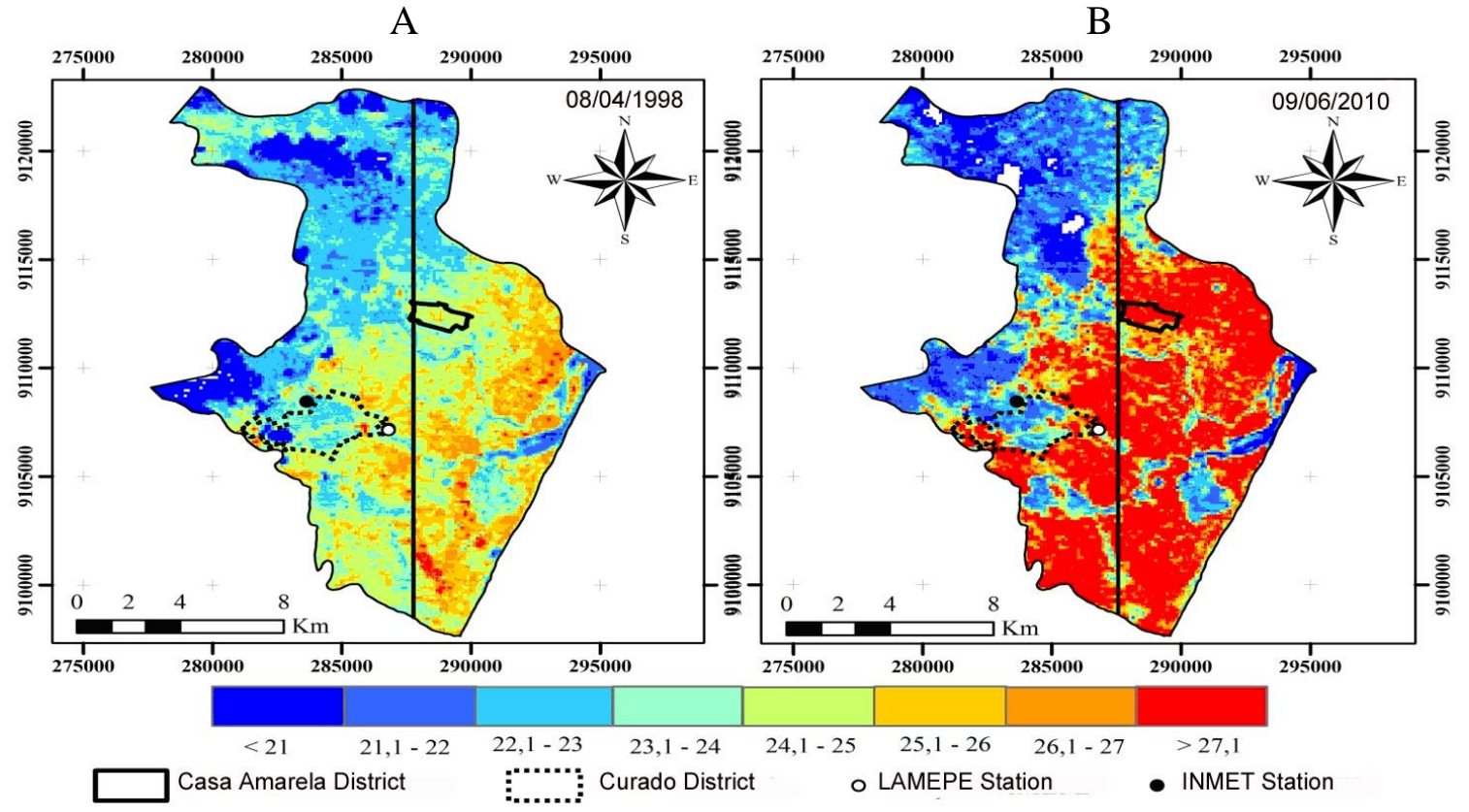

FIGURE 1. Land surface temperature for the city of Recife at 09:07am in August 4, 1998 (A) and at 09:19am in September 6, 2010 (B).

The areas with higher values of Ts, represented in yellow to reddish tones, corresponded to areas with low vegetation, bare soil and urban area, resulting in values higher than $24^{\circ} \mathrm{C}$. These values are consistent with those obtained by MOREIRA \& GALVÍNCIO (2007), who found values of Ts greater than $25^{\circ} \mathrm{C}$, for the same study area. ARAUJO \& DI PACE (2010) obtained for of Maceió city - Alagoas (AL), in Brazil, Ts values ranging from 26.5 to $32^{\circ} \mathrm{C}$, in large parts of the urban sprawl of the city of Maceió-AL, caused by the substitution of natural surfaces by artificial materials, such as asphalt and concrete. FEITOSA et al. (2011) obtained values of Ts between 23$35^{\circ} \mathrm{C}$ in the central city of Teresina-PI. By comparing the maps between the days 4 August, 1998 and 6 September, 2010, the changes were noticeable in Ts, indicating a difference of more than $2{ }^{\circ} \mathrm{C}$. This variation is a result of various factors, among which stands out the density of vertical and horizontal constructions in urban areas, causing a low concentration of green areas, making the temperature higher than the surrounding non-urbanized areas.

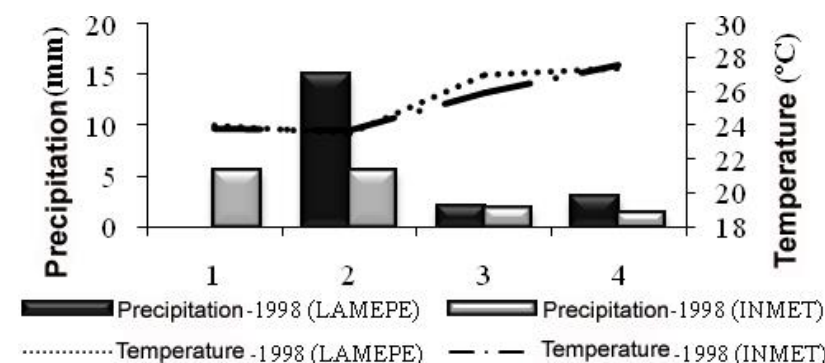

A

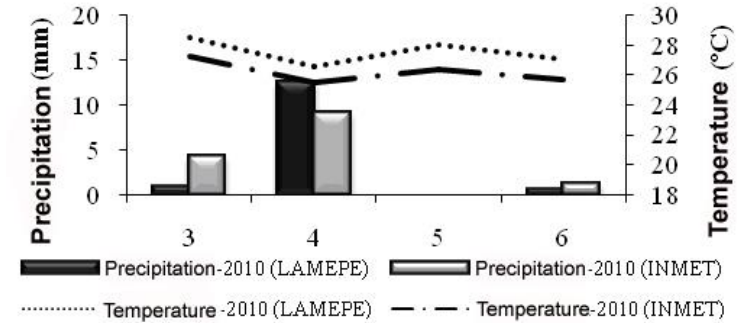

B

FIGURE 2. Daily precipitation and mean air temperature, recorded at INMET and LAMEPE stations between August 1 to 4, 1998(A) and September 3 to 6 2010(B).

Figure 2 depicts the mean air temperature and daily precipitation for the days that preceded the imaging of the study area, recorded at the stations of the National Institute of Meteorology (INMET - Instituto Nacional de Meteorologia) and Meteorological Laboratory of Pernambuco (LAMEPE - Laboratório de Meteorologia de Pernambuco). The data of the conventional station correspond to the synoptic time of $12 \mathrm{pm}$, i.e. $9 \mathrm{am}$ local time, being very close to the time of the passage of Landsat 5 in Recife-PE. Analyzing the air temperature for the date of August 4, 1998 (Figure 2A), it is clear that there was no great difference between the values obtained in the two 
seasons, while for the date of September 6, 2010 (Figure 2B), as can be seen, there were variations in the temperature of the air between the stations, with a difference of $2.2^{\circ} \mathrm{C}$. The daily precipitation records prior to the date of August 4, 1998 were higher compared with the date of September 6, 2010, as both dates are in different seasons. This may have influenced the values of Ts, and influence the values of the average air temperature.

Another factor to consider is getting these images in different periods of the year (August and September), which will provide a variation in the zenith angle capable to influence the incident solar radiation at the time of local passage of the Landsat. This change is due to the apparent movement of the sun throughout the year, making the declination of the Sun 5.79 in August 4, 1998 and $17.45^{\circ}$ on September 6,2010 , for this reason, the values of incident solar radiation $\left(\mathrm{R}_{\mathrm{S} \downarrow}\right)$ in the study area suffer considerable variation between the dates (Table 2). The Ts increase between the days studied, although it is explained in part by the largest amount of incident solar radiation, is associated to excessively high density of the constructions, which can be determined by evaluating the changes in NDIV in the transects plotted in Figure 2.

TABLE 2. Data of images and other parameters relating to the study area: local time, Julian day $(J D)$, Sun's declination $(\delta)$, the inverse square of the Earth-Sun distance (dr), cosine of the zenith angle (coz Z) and instantaneous solar radiation (Rs $\downarrow$ ).

\begin{tabular}{ccccccc}
\hline Date & Hour (GMT) & JD & $\delta$ (degrees) & $\mathrm{dr}$ & $\mathrm{Cos} \mathrm{Z}$ & $\mathrm{R}_{\mathrm{S} \downarrow}\left(\mathrm{W} \mathrm{m}^{-2}\right)$ \\
\hline $08 / 04 / 1998$ & $12: 07^{\prime} 48^{\prime}{ }^{\prime}$ & 216 & 17.45 & 0.9723 & 0.732 & 729.5 \\
$09 / 06 / 2010$ & $12: 19^{\prime} 42^{\prime}$, & 249 & 5.79 & 0.9864 & 0.835 & 843.1 \\
\hline
\end{tabular}

Through the thematic maps of Ts (Figures 1A and 1B) and the NDVI data, we plotted the profiles in transect of the study area (Figures 3A and 3B). Thus, it was possible to observe more clearly the spatial and temporal variation of Ts in relation to NDVI in both dates. We found in this way, the increase in Ts toward the suburb to the central part of Recife-PE (north-south direction), resulting in a temperature difference between the peripheral zones and the center of $6^{\circ} \mathrm{C}$ for August 4, 1998 and $10^{\circ} \mathrm{C}$ for September 6, 2010. These changes result from various anthropogenic interferences suffered in the region, including the elimination of natural environments by replacement of built environments and the density of the buildings. We also found that the Ts for September 6, 2010, in general, was higher compared to August 4, 1998. Between the relative distances of the 400 and 700 pixels, there was a clear reduction in NDVI and consequent increase in Ts. This fact is also noticeable between 780 and 1040 pixels (Figure 3), when we visually evaluate the behavior of Ts and NDVI between the two investigated dates.

A

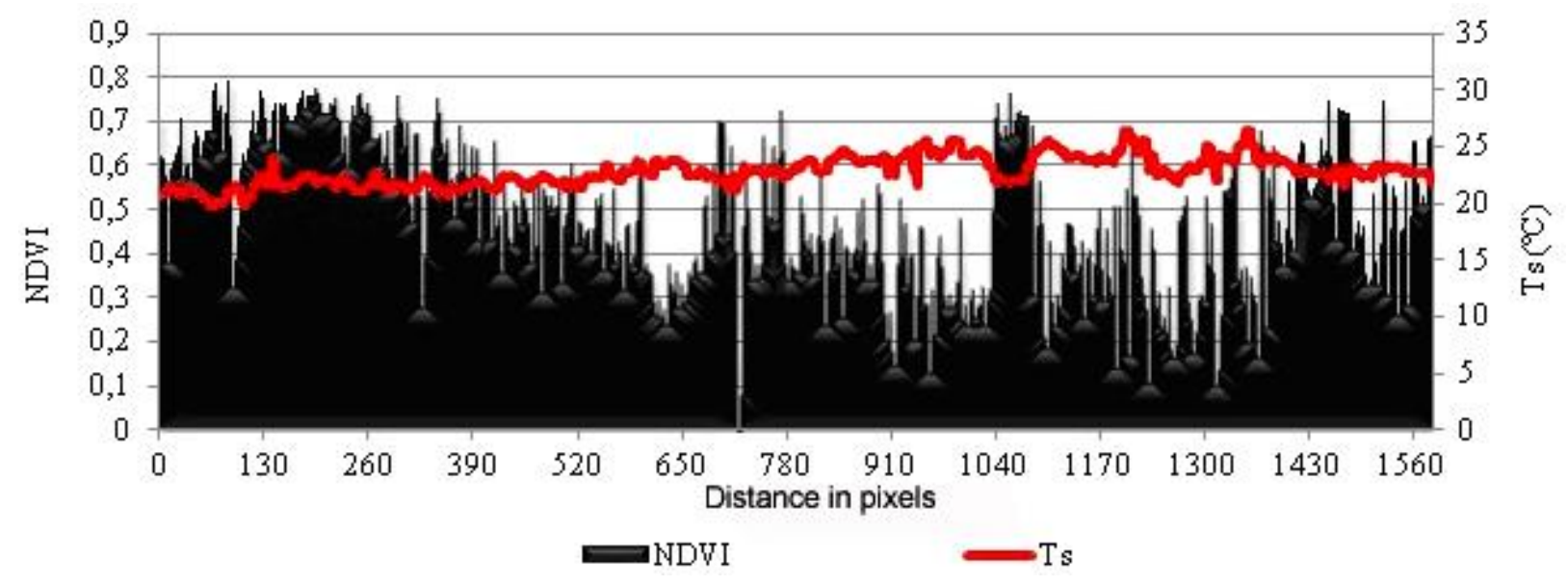


B

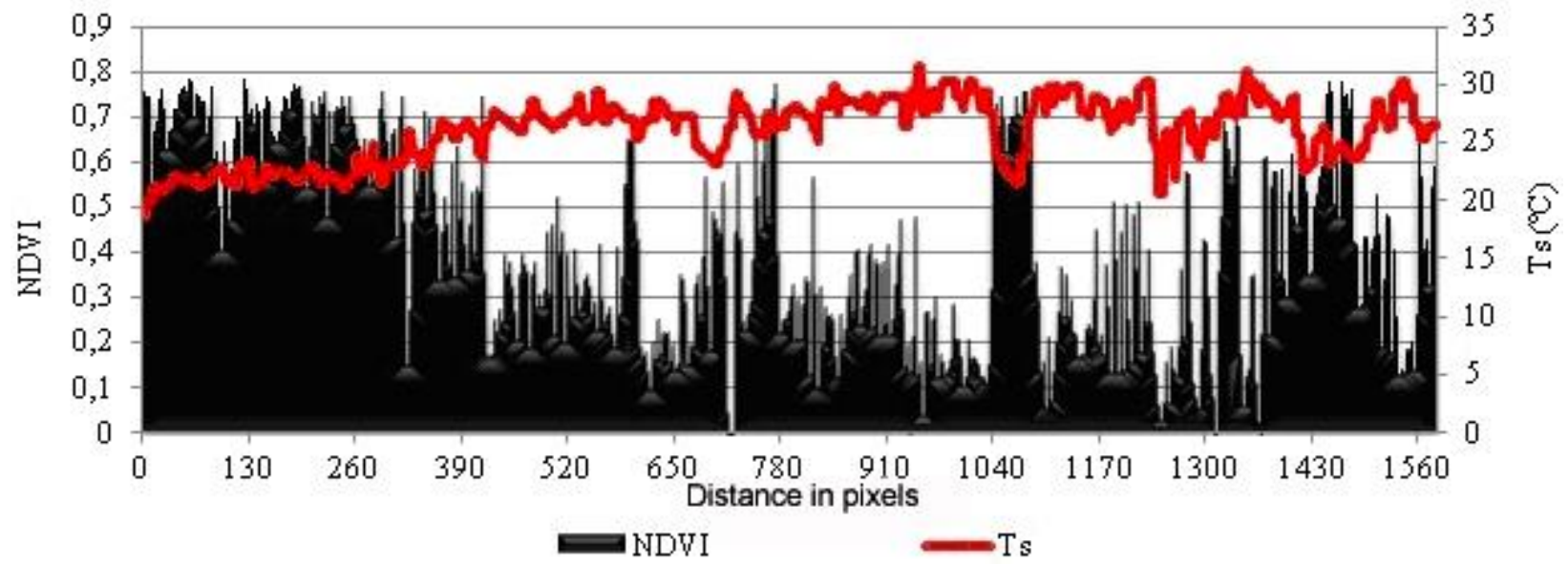

FIGURE 3. Profiles of Ts related with NDVI, in August 4, 1998(A) and September 6, 2010 (B).

The highest values of Ts are present in an area with large agglomeration of buildings, or even in area of exposed soil, lying above $25^{\circ} \mathrm{C}$ for August 4, 1998 and $29^{\circ} \mathrm{C}$ for September 6, 2010. The lowest values were observed in the area with water features and spaces with greater presence of vegetation, with temperatures ranging from $20-23^{\circ} \mathrm{C}$, at both dates. For a better analysis of the results, we chose to highlight two areas with distinct characteristics, of Recife-PE: districts of Casa Amarela (shows areas with urban density and low green area) and Curado (higher green area and little urban density).

In the analysis to the district of Casa Amarela (Figures $4 \mathrm{~A}$ and 4B), we observed that the lowest values of Ts were obtained on August 4, 1998, with values between $24-26^{\circ} \mathrm{C}$ throughout most of its length. The highest values of Ts were recorded on September 6, 2010, being estimated above $26^{\circ} \mathrm{C}$, values very consistent with those obtained by ARAÚJO \& DI PACE (2010) analyzing districts with heavy density of vertical and horizontal constructions in Maceió-AL that averaged between $26-32^{\circ}$ C. Similar values were also found by NÓBREGA \& VITAL (2010), evaluating the influence of urbanization on the microclimate of Recife-PE and formation of heat island in local districts of Boa Vista and Várzea.

We also found that the district of Casa Amarela showed great Ts variation between the studied days, evidenced by an average increase of $2^{\circ} \mathrm{C}$ between the days in question. This heating can be related mainly to continued urban growth in the district, concerning to the built environment and the impermeability of the soil, tied to reduced vegetation cover, contributing to a greater concentration of heat. These combinations of factors promote significant changes in the physical structure of the surface, contributing to the increase of air temperature, which leads to the formation of the heat island. According to AMORIM et al. (2009), the increase of Ts is caused by changes in the physical characteristics, such as high density constructions, materials of high concentrations of potential energy reflectance and emissivity, and urban activities. The thermal response of the urban structure showed that urbanization and land use characteristics are responsible for the distribution of air temperature by generating heat islands in densely built districts, or the concentration of construction materials with great energy potential of reflectance and emissivity. 


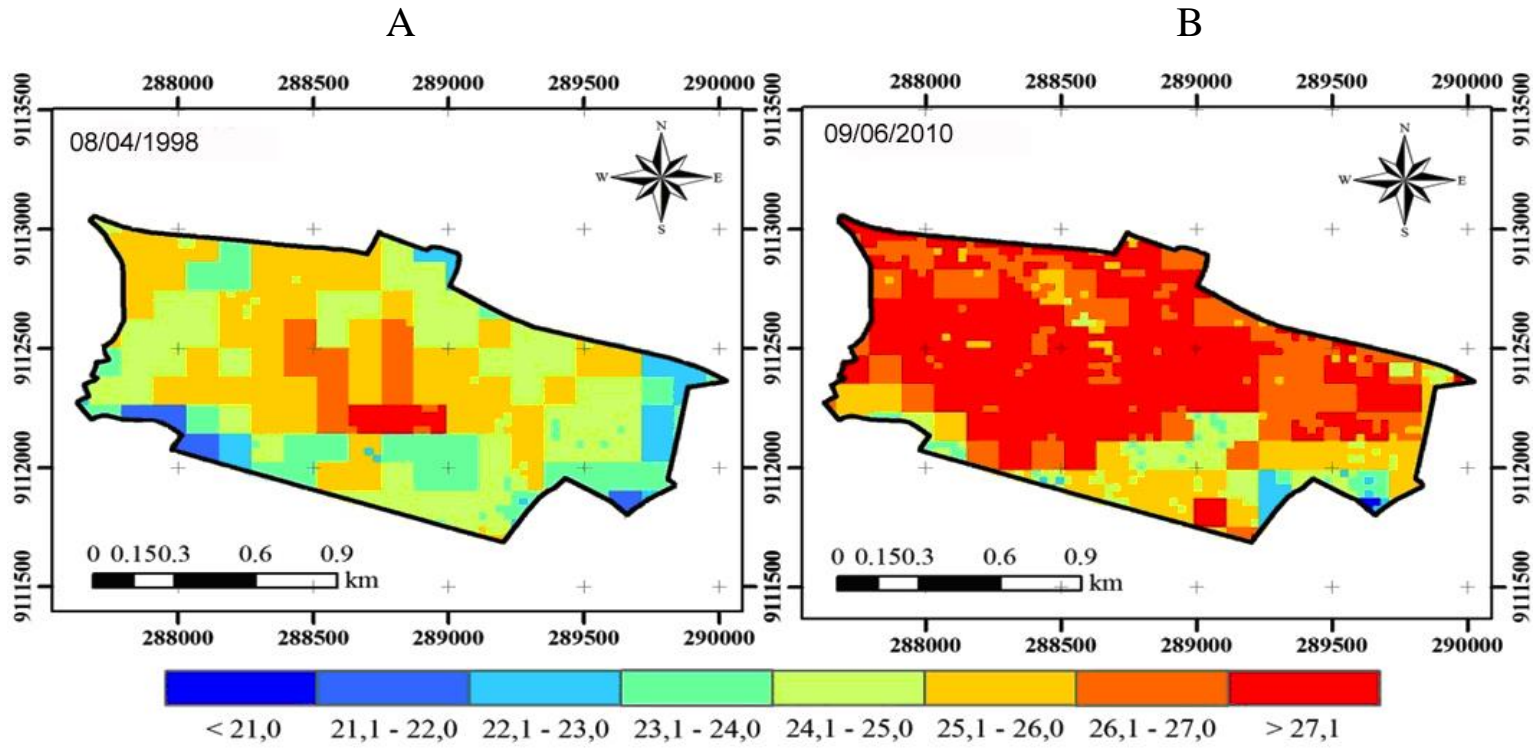

FIGURE 4. Thematic maps of land surface temperature for the district of Casa Amarela at 09:07am in August 4, 1998 (A) and at 09:19am in September 6, 2010 (B).

Figures 5A and 5B show the thematic maps of Ts to the district of Curado. We observed that on August 4, 1998 the district had mostly Ts values below $24^{\circ} \mathrm{C}$, justified by a locality with high density vegetation, where the vegetation will intercept the incident radiation and the radiation that comes from the forest, having a direct effect on the temperature. As a consequence, the shading decreases the Ts, and on the other hand, colder surfaces also reduce the heat transmitted to the building and the atmosphere (COSTA et al. 2010). Another factor is that green leaves do not heat as much as the soil and the plant litter layer. Moreover, $50-60 \%$ of the incident solar radiation are employed in the evapotranspiration process and can be identified as the main factor of the Ts reduction (SILVA et al., 2011). However, for the same date already mentioned, there was occurrence of clouds in the western part of the district, resulting in temperatures lower than $21.5^{\circ} \mathrm{C}$, not adequately portraying the expected value in this area.

A

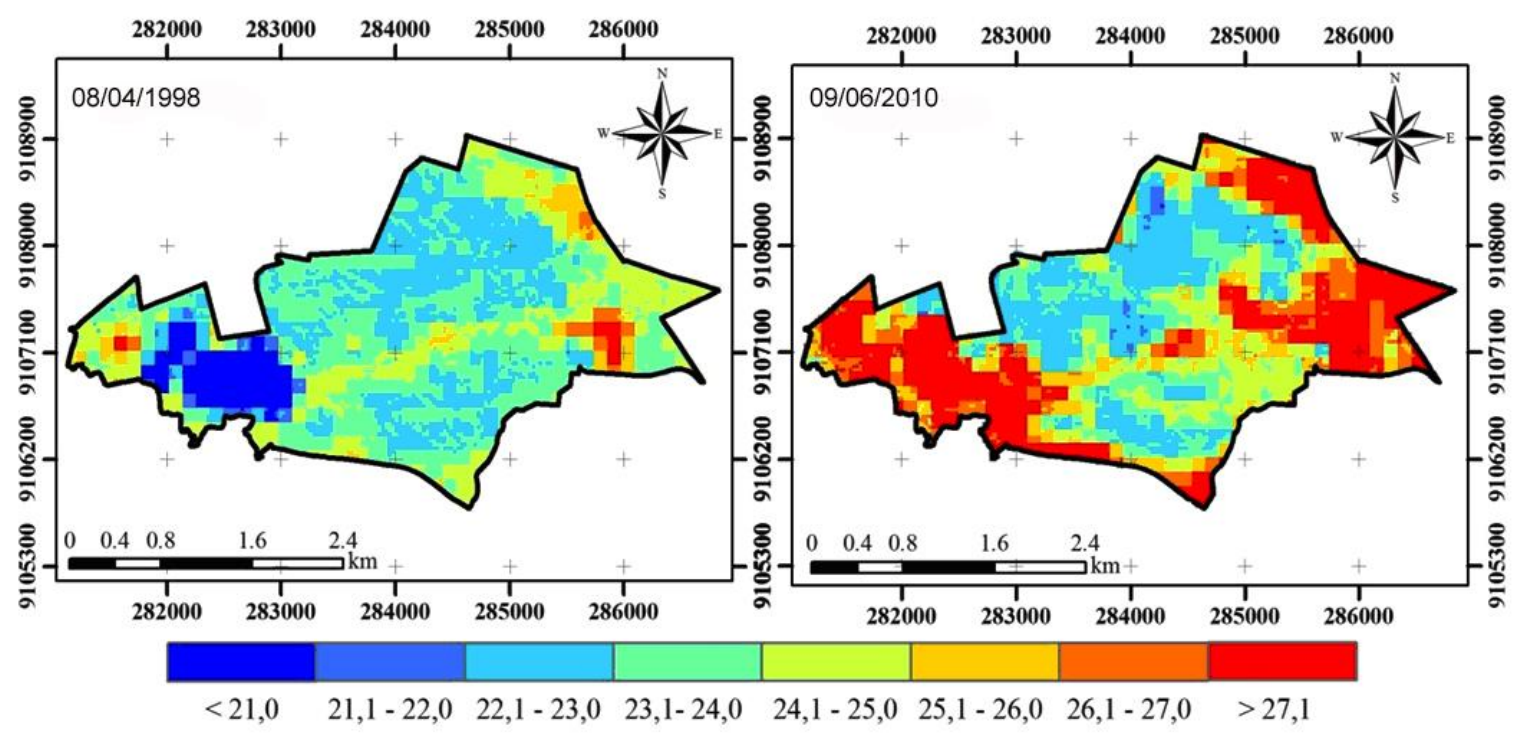

FIGURE 5. Thematic maps of land surface temperature of district of Curado at 09:07am in August 4, 1998 (A) and at 09:19am in September 6, 2010 (B). 
The highest values of Ts were recorded on September 6, 2010 and can be explained by the greater amount of energy, due to the low proportion of vegetation on the area with high construction density associated to the predominance of verticalization, resulting in temperatures higher than $24.5^{\circ} \mathrm{C}$. These results demonstrate that the district has suffered some changes over the years, with $1.5^{\circ} \mathrm{C}$ difference between the dates studied, which will contribute to the increase of air temperature in the region.

\section{CONCLUSIONS}

The Ts, in general, increased by approximately $2^{\circ} \mathrm{C}$ between the days studied. The highest surface temperatures are within the urban sprawl of the city, with recorded values above $27^{\circ} \mathrm{C}$, for the date of September 6, 2010.

Through the profiled outlined for the study area, there was a noticeable increase in the spatial and temporal surface temperatures towards suburb-center, resulting in a difference of $6^{\circ} \mathrm{C}$ between these areas. We can attribute the increase in Ts to the intensification of the anthropization process of the urban space, although it should not be disregarded the contribution offered by global solar radiation, which in the 2010 image was about 15\% higher than the value recorded at the time of imaging the 1998 image.

The district of Casa Amarela, with greater urban density and large amount of vertical and horizontal constructions, is distinguished by presenting higher Ts, compared to the district of Curado, presenting up to $27^{\circ} \mathrm{C}$ on the date of September 62010.

\section{ACKNOWLEDGEMENTS}

Coordination of Improvement of Higher Education Personnel (CAPES - Coordenação de Aperfeiçoamento de Pessoal de Nível Superior) by supporting the development of this study, National Council for Scientific and Technological Development (CNPq - Conselho Nacional de Desenvolvimento Científico e Tecnológico) and National Institute for Space Research (INPE Instituto Nacional de Pesquisas Espaciais), for the availability of Landsat 5 TM images.

\section{REFERENCES}

ALLEN, R.G.; TASUMI, M.; TREZZA, R. Satellite-based energy balance for mapping evapotranspiration with internalized calibration (METRIC)-model. Journal of Irrigation and Drainage Engineering, Reston, p.380-394, 2007.

AMORIM, M.C. de C.T.; DUBREUIL, V; QUENOL, H.; SANT’ANA NETO, J.L.S.

Características das ilhas de calor em cidades de porte médio: exemplos de Presidente Prudente (Brasil) e Rennes (França). Confins, n. 7, 2009. Online. Disponível em:

<revues.org/index6070.html>. Acesso em: 25 jan 2012.

ARAUJO, T.L.; DI PACE, F.T. Valores instantâneos da temperatura da superfície terrestre na cidade de Maceió-AL utilizando imagens do satélite TM/Landsat 5. Revista Brasileira de Geografia Física, Recife, v.3, n.2, p.104-111, 2010.

BEZERRA, B.G.; SILVA, B.B.; FERREIRA, N.J. Estimativa da evapotranspiração real diária utilizando-se imagens digitais TM - Landsat 5. Revista Brasileira de Meteorologia, São José dos Campos, v.23, n.3, p.305-317, 2008.

CHANDER, G.; MARKHAM, B.L.; HELDER, D.L. Summary of current radiometric calibration coefficients for Landsat MSS, TM, ETM+, and EO-1 ALI sensors. Remote Sensing of Environment, Oxford, v.113, p.893-903, 2009.

CHEN, X.L.; ZHAO, H.M.; LI, P.X.; YIN, Z.Y. Remote sensing image-based analysis of the relationship between urban heat island and land use/cover changes. Remote Sensing of Environment, Oxford, v.104, p.133-146, 2006. 
CHRISTEN, A.; VOGT, R. Energy and radiation balance of a Central European city. International Journal of Climatology, Chichester, v.24, p.1.395-1.421, 2004.

CODATO, G.; OLIVEIRA, A.P.; SOARES, J.; ESCOBEDO, J.F.; GOMES, E.N.; PAI, A.D. Global and diffuse solar irradiances in urban and rural areas in southeast of Brazil. Theoretical and Applied Climatology, Wien, v.93, n.1-2, p.57-73, 2008.

COSTA, D.F. da; SILVA H.R.; PERES, L. de F. Identificação de ilhas de calor na área urbana de Ilha Solteira-SP através da utilização de geotecnologias. Engenharia Agrícola, Jaboticabal, v. 30, n.5, p.974-985, set./out. 2010.

DI PACE, F.T.; SILVA, B.B.; SILVA, V.P.R.; SILVA, S.T.A. Mapeamento do saldo de radiação com imagens Landsat 5 e modelo de elevação digital. Revista Brasileira de Engenharia Agrícola e Ambiental, Campina Grande, v.12, n.4, p.385-392, 2008.

FEITOSA, S.M.R.; GOMES J.M.A.; MOITA NETO J.M.; ANDRADE C.S.P. de. Consequências da urbanização na vegetação e na temperatura da superfície de Teresina- Piauí. Sociedade Brasileira de Arborização Urbana, Piracicaba, v.6, n.2, p.58-75, 2011.

FERREIRA, M.J.; OLIVEIRA, A.P.; SOARES, J.; CODATO, G.; BÁRBARO, E.W.; ESCOBEDO, J.F. Radiation balance at the surface in the city of São Paulo, Brazil: diurnal and seasonal variations. Theoretical and Applied Climatology, Wien, v.107, n.1-2, p.229-246, 2012.

HONORATO, A.F.A.; ANDRADE, V.S.da A. Ilhas de calor e frescor na área urbana da cidade de Aquidauana-MS. Revista Geonorte, Amazonas, v.2, n.4, p.878-886, 2012. Edição especial.

HUETE, A. R. A soil adjusted vegetation index (SAVI). Remote Sensing of Environment, Oxford, v.25, p. 295-309, 1988.

IBGE. Instituto Brasileiro de Geografia e Estatística. Primeiros Resultados do Censo 2012. Disponível em: < http://www.ibge.org.br >. Acesso em: 25 mar. 2013.

KATO, S.; YAMAGUCHI, Y. Analysis of urban heat-island effect using ASTER and ETM+ data: separation of anthropogenic heat discharge and natural heat radiation from sensible heat flux. Remote Sensing of Environment, Oxford, v.99, p.44-54, 2005.

MOREIRA, E.B.M.; GALVÍNCIO, J.D. Distribuição espacial das temperaturas à superfície na cidade do Recife, utilizando imagens TM Landsat - 7. Revista Brasileira de Geografia Física, Recife, v.20, n.3, p.77-89, 2007.

MOREIRA, E.B.M.; NÓBREGA, R.S.; SILVA, B.B. Estimativa do saldo de radiação instantâneo na cidade do Recife, através de imagens do satélite Landsat 5 TM. Revista Brasileira de Geografia Física, Recife, v.4, n.3, p.589-601, 2011.

NÓBREGA, R.S.; VITAL, L.A.B. Influência da urbanização sobre o microclima de Recife e formação de ilha de calor. Revista Brasileira de Geografia Física, Recife, v.3, n.3, p.151-156, 2010.

OLIVEIRA, L. M. M. de. Análise quantitativa de parâmetros biofísicos de bacia hidrográfica obtidos por sensoriamento remoto. Revista Pesquisa Agropecuária Brasileira, Brasília, v.47, n.9, p.1209-1217, 2012.

OKE, T. R.; MAXWELL, G. B. Urban heat island dynamics in Montreal and Vancouver. Atmospheric Environment, Oxford, v.9, p.191-200, 1975.

RITTER, M.E. The Physical Environment: an Introduction to Physical Geography. Climate. Disponível em:<http://www.uwsp.edu/geo/faculty/ritter/geog101/textbook/climate_systems/ urban_climate.html >. Acesso em: 15 dez. 2011.

RODRIGUES, J.O. da; ANDRADE, E.M. de; TEIXEIRA A. dos S.; SILVA, B.B. Sazonalidade de variáveis biofísicas em regiões semiáridas pelo emprego do sensoriamento remoto. Engenharia Agrícola, Jaboticabal, v.29, n.3, p.452-465, jul./set. 2009. 
ROTH, M. Review of urban climate research in (sub) tropical regions. International Journal of Climatology, Chichester, v.27, p.1859-1873, 2007.

SILVA, B.B.; MENDONÇA, R.R.O.; SILVA, S.T.A.; FERREIRA, R.C. Mapeamento do albedo de áreas heterogêneas no estado do Ceará com imagens TM - Landsat 5. Revista de Geografia, Recife, v.25, n.2, p.33-52, 2008.

SILVA, B.B.; BRAGA, A.C.; BRAGA, C.C. Balanço de radiação no perímetro irrigado São Gonçalo - PB mediante imagens orbitais. Revista Caatinga, Mossoró, v.24, n.3, p. 145-152, 2011.

TASUMI, M.; ALLEN, R.G.; TREZZA, R. At surface reflectance and albedo from satellite for operational calculation of land surface energy balance. Journal of Hydrologic Engineering, London, v.13, n.2, p. 51-63, 2008. 